\title{
Growing 'Smart'? Urbanization Processes in the Pune Urban Agglomeration
}

\author{
Carsten Butsch 1,*, Shamita Kumar 2,* (D), Paul D. Wagner ${ }^{3}$ (D), Mareike Kroll ${ }^{1}$, \\ Lakshmi N. Kantakumar $^{2}$ (D), Erach Bharucha ${ }^{2}$, Karl Schneider ${ }^{4}$ (D) and Frauke Kraas ${ }^{4}$ \\ 1 Institute of Geography, University of Cologne, Cologne 50923, Germany; mareike.kroll@uni-koeln.de \\ 2 Institute of Environment Education and Research, Bharati Vidyapeeth Deemed University, Pune 411043, \\ India; Lakshmikanth@bvieer.edu.in (L.N.K.); erach.bharucha@bvieer.edu.in (E.B.) \\ 3 Department of Hydrology and Water Resources Management, Institute for Natural Resource Conservation, \\ Kiel University, Kiel 24118, Germany; pwagner@hydrology.uni-kiel.de \\ 4 Institute of Geography, University of Cologne, 50923 Cologne, Germany; karl.schneider@uni-koeln.de (K.S.); \\ f.kraas@uni-koeln.de (F.K.) \\ * Correspondence: butschc@uni-koeln.de (C.B.); shamita@bvieer.edu.in (S.K.)
}

Received: 29 October 2017; Accepted: 5 December 2017; Published: 14 December 2017

\begin{abstract}
The Indian city of Pune witnessed rapid growth and deep transformation processes in the last three decades. This paper assesses past developments and recent structures and processes against the concept of urban sustainability. Following an overview of the historical development, the dimensions of sustainability are discussed separately, based on empirical findings. Urban growth puts enormous pressure on Pune's land and water resources, changing the ecology of the area. The increasing water demand of Pune's growing population competes with growing energy and water demands. An assessment of future climate change impacts indicates that the storage capacity of the reservoirs is more frequently not met during the rainy season. In addition, extreme dry years can aggravate the effects of land use change on water resources in the future. The city's growth and especially the large in-migration has also changed Pune's social fabric significantly. Wealth is distributed unevenly in the city and social disparities can be observed along two fault lines, namely along classes and caste groups. The population development and the increasing socioeconomic polarization are linked to the economic development of the city. Pune's formal economy has a robust base. However, as in many cities of the Global South, the informal economy is the most relevant source of income for large parts of the population. Pune's development is challenged by informality, poor infrastructure and inadequate planning and governance. Recently new approaches towards urban renewal and smart city development were launched. These new approaches aim at overcoming blockades in the traditional planning. A special challenge for urban planning is the transformation of urban fringe areas of the city, as this process is currently taking place in an unsustainable manner. The paper concludes that urban development has to become holistic, integrative and participative and should abandon the stereotype vision of the world class city in favor of a sustainable, locally adjusted pathway of development.
\end{abstract}

Keywords: sustainability; urbanisation; ecological resources; social disparities; informality; planning processes; Pune; India

\section{Introduction}

Urbanisation in low and middle-income countries is one of the most influential transformation processes, altering urban as well as natural systems on the local, regional and global scale. The report of the World Commission on Environment and Development underlined the challenge of urban transformation for sustainable development and large parts of its analysis are still to the point — even after 30 years [1]. 
Yet, urban transformation offers opportunities and challenges to create sustainable habitats for the future. As the two British development agencies UKAID and DFID note in a joint report: "the earlier cities in developing countries take steps to future proof their urban development, the better. There is an important-but closing — window of opportunity for many cities to act now before they are locked into unsustainable and unsuitable development pathways" ([2], p. ix). The New Urban Agenda formally adopted in 2016 in Quito also highlights the decisive role of cities in developing countries in the urban-based globalization proces [3]. One of the key concerns is that especially rapid growth deserves attention in the planning and management of urbanization through effective governance. Effective governance must recognize the potential and limits of the planning process, it must acknowledge the opportunities and challenges of spontaneous and informal development, be cognizant of the natural systems which provide the essential base (e.g., water, food, energy) for urban livelihood, and address the mutual risks which natural system dynamics pose on urban systems-and vice versa. Thus, analyzing the urbanization process is in fact a prime example of the complexity of human-environment research. The complexity of the issue at hand demands a paradigm shift to achieve sustainable development, especially in low and middle-income countries. Drawing on the example of Pune, this paper aims at bringing together some key aspects of this complex issue by addressing processes of natural environment, urban development processes and governance issues. Pune's development is symptomatic for many cities in the world. It faces a very dynamic urban growth and dwindling environmental resources to sustain this growth. Based upon the city's development trajectory, the multidisciplinary perspective assumed in this paper helps to identify emerging issues of urban development and emphasizes the role of policies and governance in sustainable urban development.

Pune (once Poona) has witnessed rapid growth and deep transformation processes, especially in the last three decades. After Indian independence, the city grew remarkably in connection with the city's regional and agricultural embedding, the national policy for the diversification of industries and the existing renowned educational facilities. Today, Pune is India's eighth largest urban agglomeration (ninth largest municipality) with 5 million inhabitants in 2011 [4]. Situated $160 \mathrm{~km}$ south-east of the country's largest and economically most important city, Mumbai, Pune in the past used to offer less business opportunities and was comparatively less connected to global processes. Instead, it offered a higher quality of life: Pune was a place for those escaping Mumbai but who still wanted to stay connected.

Remarkable growth since 1991 brought about deep changes to Pune, which was dominated mainly by its universities and the military-as being the seat of the Indian Army's Southern Command. Pune today has a diverse economic structure and a well-connected infrastructure. It is part of a larger urban development corridor stretching from Ahmedabad via Mumbai to Pune [5]. Within the State of Maharashtra, this urban corridor (namely with the districts of Mumbai, Thane and Pune) shows highest values of the Human Development Index [6]. The future plans envisage an integration into the Delhi-Mumbai Industrial Corridor (DMIC) with an infrastructural upgrade and the creation of a large industrial zone (planned as 'node 19': Pune-Khed-industrial area, about $100 \mathrm{~km}^{2}$ ) [7]. Currently, Pune aims at transforming into a 'smart' city, the 'most livable city in India' [8].

This paper aims at assessing past developments and recent structures and processes against the concept of urban sustainability. It is based on findings from five research projects jointly undertaken by the Institute for Environment Education and Research, Bharati Vidyapeeth University Pune/India, and the Institute of Geography, University of Cologne/Germany. The projects addressed different issues on different spatial scales with a study on the water resources, taking the regional scale as the level of analysis and the studies on urban health taking the household as the level of investigation. Findings are brought together to provide an integrated view of the development of the city and its environment. Following an overview of the historical development, the four dimensions of sustainability will be discussed separately: (1) urban ecology and the utilization of ecosystem services, especially water from the surrounding areas; (2) the social conditions in the city, with a spotlight on six neighborhoods; (3) the development and structure of the city's economy; and (4) governance issues. Drawing on joint research projects, two specific developments will be discussed as crosscutting themes for sustainable 
development, namely urban health and waste management issues. In the discussion we will reflect upon the findings from the empirical case studies against the goal of sustainable development and will also address transformations that are currently taking place in Pune's urban fringe.

\section{Methods}

The article integrates work done in the frame of four different projects jointly carried out by researchers from Bharati Vidyapeeth University and University of Cologne. The approaches utilized here integrate process based environmental modelling, remote sensing, GIS analyses, qualitative and quantitative field surveys, statistical analyses and literature reviews. The approaches utilized in different projects are briefly outlined in the following paragraph.

The first project was jointly conducted by Paul D. Wagner, Shamita Kumar and Karl Schneider. Using the Soil and Water Assessment Tool (SWAT 2009, USDA, Temple, TX, USA) [9] wherein impact of land use and climate change upon the water resources of the Mula and Mutha Rivers catchment upstream of Pune, India $[10,11]$ was analysed. The urban development of Pune has led to significant land use change also in the upstream watershed of the Mula and Mutha Rivers. This change was analysed using three multitemporal land use classifications for the years 1989/1990, 2000/2001, and 2009/2010. The impact of urban growth upon the declining semi-natural land cover types and increasing cropland area is quite obvious. Using these land use maps, soil and climate data, a hydrological model was set up for the Mula and Mutha Rivers catchment upstream of Pune [12,13]. The model was evaluated with the measured daily values of river runoff during the rainy season. A reasonable performance of the model is indicated through various indices (e.g., Nash-Sutcliff efficiencies of 0.68 and 0.67 , percentage bias of $+4 \%$ and $+24 \%$ for two different gauges, respectively). The model was used to (i) analyse the impacts of land use changes between 1989 and 2009 on the water resources [10], to (ii) analyse the impact of climate change on the water resources based on downscaled future climate projections up to the year 2079 [14], and to (iii) analyse the impacts of possible future land use and climate change on the water resources using land use projections from the model SLEUTH $[15,16]$ in combination with the downscaled climate projections.

The method to address land use change in the first project is based upon satellite observations. This approach provides evidence of change but no detailed explanation of the spatial patterns of urban development. Thus, based upon the analysis of LANDSAT satellite images acquired between 1992 to 2013, the second project aimed at (i) quantifying and analysing the urban expansion process, (ii) developing a typology of urban development processes for every administrative unit of the study area in last 21 years, and (iii) modelling urban growth using the SLEUTH model [17]. Urban expansion metrics (e.g., expansion contribution rate, expansion percentage of change, annual expansion rate) were calculated for each administrative unit in the Pune metropolis and used to explain the temporal dynamics of urbanization of each individual spatial unit [18]. SLEUTH was also used to model land use change in the Mula and Mutha watershed and thus to assess the impact of land use change outside of the urban area [16]. The integration of the land use change model allows to address the combined impact of future land use and climate change.

While the first project provided evidence of change at the macro level and the second project provided an insight into the spatial patterns of urban development at the city level, the third project addressed the specific issue of change in the quality and spatial extent of green spaces within the city of Pune as a result of the urban change process. It was jointly conducted by Shamita Kumar, Lakshmi N. Kantakumar and Erach Bharucha. Green spaces are one of the key indicators within the sustainable development framework, being important for mental, physical and social well-being. Landsat images acquired between 1992 and 2013 were used to determine the change in the nature of urban greens and analysed with reference to urban change analysis in the second project for determining the causes of change.

The fourth project was jointly conducted by Frauke Kraas, Mareike Kroll, Erach Bharucha and Carsten Butsch. It focused on urban health and first analysed the changing burden of disease due to the epidemiological transition taking place in Pune. Second, it investigated the access to health care services in Pune, combining the demand and supply side perspectives. Methods applied in 
these projects were: (1) a household survey in 900 randomly sampled households in six research areas, reflecting Pune's different phases of growth [19]; (2) 68 in-depth interviews with participants from the household survey, which were recorded, translated if needed, transcribed an analysed using MAXQDA; (3) 98 interviews with experts (medical practitioners, officials from the government health sector, representatives from NGO, researchers); (4) secondary data analysis.

The fifth project was jointly conducted by Mareike Kroll and Frauke Kraas. It is based on a field study in 2008 including literature search, participatory observation in the formal and informal waste collection sector and interviews with experts from the Municipal Corporation, the local trade union of waste pickers Kagad Kach Patra Kashtakari Panchayat (KKPKP) and NGOs as well as citizens and laypeople. A literature review was conducted in 2017 in order to update current structures, processes and quantities in the waste management system in Pune.

The overall view of the approaches utilized here covers a wide range of methods ranging from numerical modelling to surveys and from expert interviews to satellite image analysis, thus providing a unique method mix to address the pertinent issues of human-environment relationships in a rapidly developing urban area.

\section{Historical Development}

Historical development Pune has emerged from being the cultural capital of Maharashtra to one of the leading industrial cities of the state. The origins of Pune can be traced back to a small fishing hamlet situated at the junction of the rivers Mula and Mutha in the 1200s. The present-day structures emerged during four historical phases.

First, Pune remained a small village for centuries. Urbanization started during the era of the Peshwas, the indigenous rulers. In the 1700s, they defeated the Mughals and ruled large parts of the Deccan Plateau. They made Pune the de facto capital of large parts the country for a short period. The Peshwas, warriors with Spartan lifestyles, did hardly shape the city but developed the typical housing form of 'wada' which still shapes the larger traditional quarters of Pune today [20].

The second phase of urbanization started after the British defeated the Peshwas in the early 1800s and developed Pune as a military base, causing discontinuity in the formerly indigenous process of urbanization. Their rule saw the establishment of military cantonments, colonial style housing and public buildings. A dual identity of the city grew, of native 'peth' areas (Marathi term for neighborhoods) with narrow lanes and by-lanes and of the cantonment areas with sprawling bungalows and wide avenue roads-a dichotomy that exists even today. The two areas still nurture their distinct urban forms and cultural flavor but with increased interaction over the years; 'orderly' elements from the cantonment can be found around the core.

The third phase of urban development started from the 1960s when the trajectory of Pune's urban growth was linked with Mumbai, the capital of the state. Mumbai's industries spread towards Pune. With the establishment of the new industrial township of Pimpri-Chinchwad as Pune's new twin city, migrants from across the country moved to the area. Moreover, after the disastrous floods of 1961 resulting from a dam break in the upper catchment which destroyed large sections of the old city of Pune, new cityscapes were constructed [20].

The fourth phase was initiated in the 1990s with India's economic liberalization resulting in an opening of the Indian economy [21]. In Pune, numerous information technology and biotechnology parks emerged, shaping Pune as industrial city with cosmopolitan population. This phase saw the adoption of the Special Economic Zone Policy by the state government of Maharashtra in 2006, which led to boosting economic growth, and the Jawaharlal Nehru Urban Renewal Mission of the Government of India, which aimed at improving the urban infrastructure.

Pune's cityscape today thus contains four distinct areas-(a) the old inner city core that is influenced by the historical developments from the late 1700s, (b) the large cantonments that have been designed by the British who made Pune as one of their military bases in the 1800s and which are until today under military-based governance, (c) the new industrial areas which contribute to Pune's economic prosperity, 
and (d) the urban fringe areas which are speedily developing with a mixture of housing and informal economy. The development of Pune indicates the change of drivers of urban growth over time. Today's economic development led to an unprecedented growth of the city as well as to unprecedented impacts of this urban growth upon the rural surroundings. Pune's urban landscape today reveals a mix of authorized and unauthorized urban structures. Its development is based on a Development Plan (DP) [22] as a planning master document, which control rules are in practice often blatantly ignored.

Pune's growth is related to significant in-migration: In 1941, Pune had 375,000 inhabitants ([23], p. 174), in 2011, the population of the urban agglomeration-consisting of the Pune Municipal Corporation, the cantonments Pune and Khadki, the Pimpri Chinchwad Municipal Corporation (PCMC) and to the North Dehu Road and Dehu — crossed the threshold of five million inhabitants [4]. The population of the PMC reached 3.1 million [4]. Migrant population was at 20\%, from which two third came from the state of Maharashtra [24]. Most of the inter-state migrants came from the neighboring states Andhra Pradesh (before its bifurcation) and Karnataka. Pune Municipal Corporation estimates that the population growth rate will slow down from $3.39 \%$ (2007-2012) to $2.13 \%$ (2022-2027) [25,26]. However, PMC expects the population to grow to 5.7 million by 2027 ([10], p. 109). The World Urbanisation Prospects predict that the whole Pune urban agglomeration will reach 8.1 million inhabitants by 2030 [26].

Pune is thus growing exponentially in terms of its spatial extent (with new surrounding villages being brought under its ambit every ten years or so), its economic activities and its demography. The built-up area in Pune Municipal Corporation (PMC) has expanded about 7.5 times from $18.3 \mathrm{~km}^{2}$ in 1973 to $139.4 \mathrm{~km}^{2}$ in 2013 with an annual rate of expansion $3 \mathrm{~km}^{2}$ per annum (Figure 1). The introduction of foreign direct investment (FDI) in 1991 kick-started the process of rapid urbanization. Between 1973 and 1992, Pune witnessed only $38.5 \mathrm{~km}^{2}$ growth in the built-up areas with $2 \mathrm{~km}^{2}$ per annum. Between 1992 and 2013, the city witnessed massive growth of about $82.5 \mathrm{~km}^{2}$ of built-up areas with an expansion rate of $3.9 \mathrm{~km}^{2}$ per annum [18]. If this urban growth trends continue, $67.1 \mathrm{~km}^{2}$ additional built-up area to reach $206.4 \mathrm{~km}^{2}$ in the year 2030 (Figure 2, SLUETH urban growth model simulations) [17].

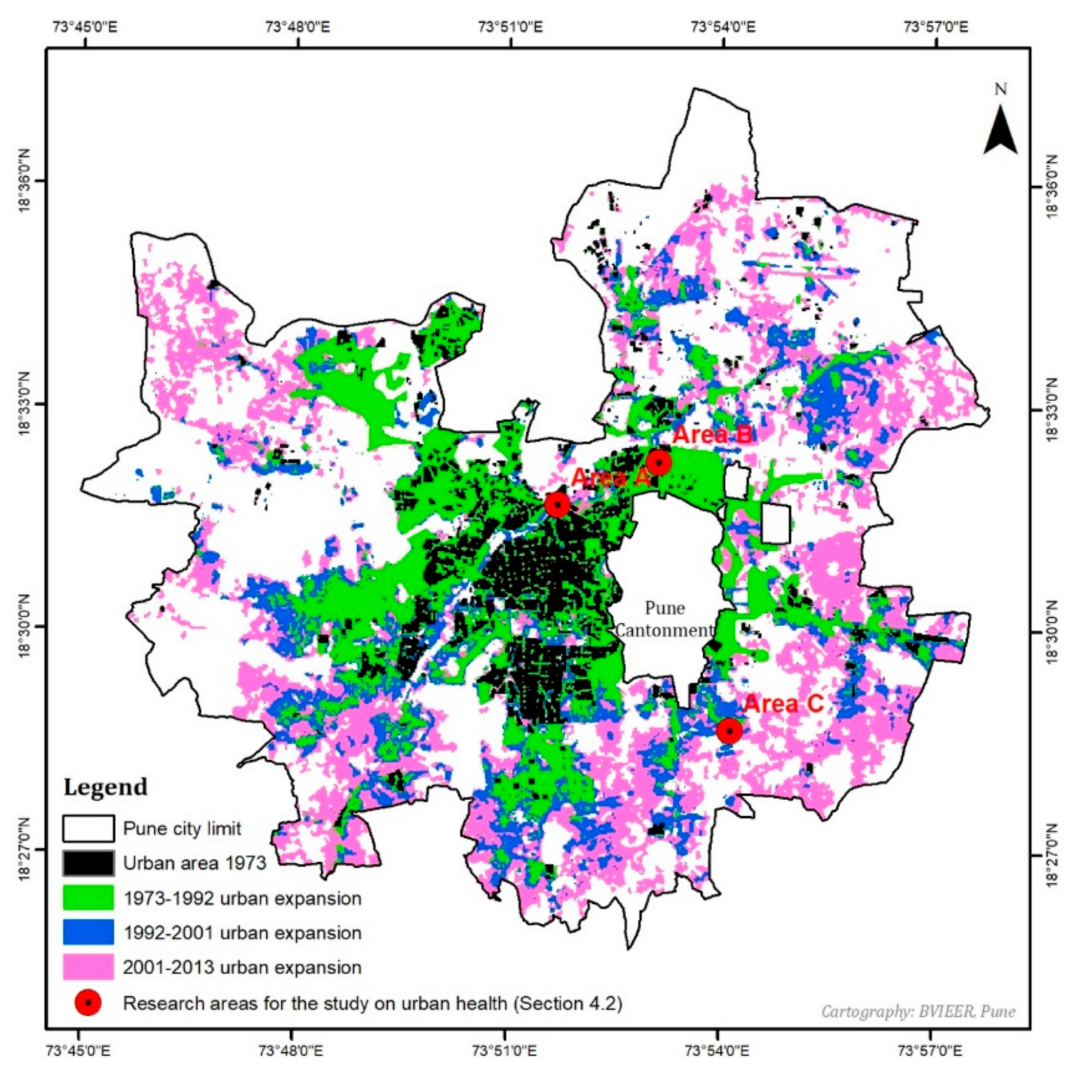

Figure 1. Expansion of Pune over time. 


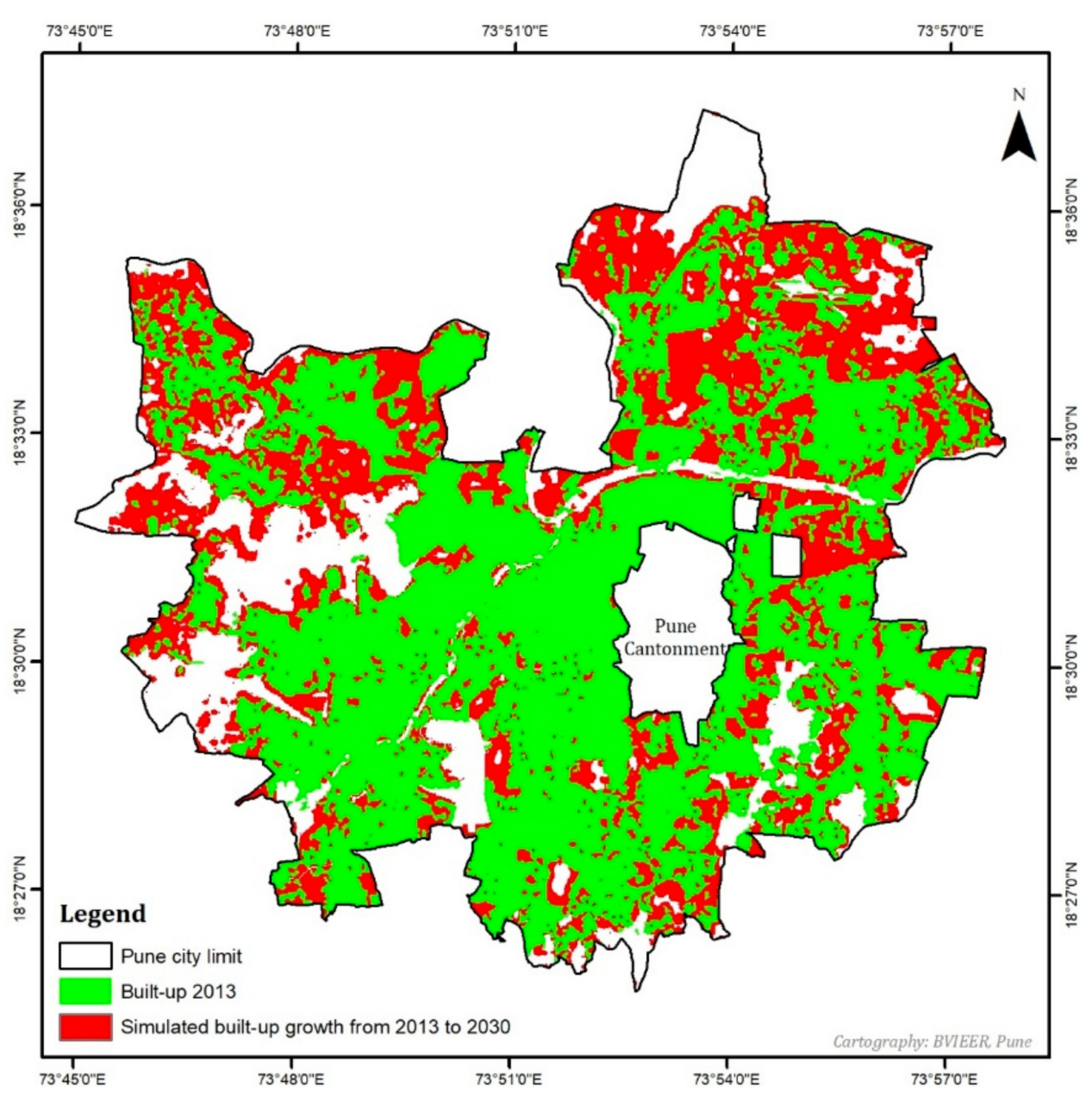

Figure 2. Expansion of Pune in 2030.

\section{Perspectives on Pune's Sustainability}

In this section, we will first discuss the state of the three dimensions of sustainability in Pune. Section 4.4 will then address politics and planning of the urban agglomeration. This section ends with examples from two fields affecting the daily lives the citizens of Pune, namely, urban health and waste management (Section 4.5).

\subsection{Land and Water Resources of Pune}

Rapid urbanization puts enormous pressure on land and water resources, changing the resource availability as well as ecology of the area. Pune is surrounded by hills and has the Western Ghats on its western boundary along with three main lakes within the city and several in the surrounding catchments as important water resources. Pune relies on the freshwater resources supplied by the upstream catchment of the Mula and Mutha Rivers (Figure 3) that join at Pune's Sangam Bridge. Water resources are primarily defined by the amount of rainfall that is received during the monsoon season from June to September. While Pune receives about $750 \mathrm{~mm}$ annual rainfall, the amounts increase towards the western edge of the catchment up to approximately $3500 \mathrm{~mm}$ annual rainfall $[27,28]$. This west to east decrease can be explained by the decreasing elevation east of the Western Ghats escarpment, which constitutes the main orographic barrier for the south-west monsoon [13].

To provide year-round water supply, water resources are stored in six large dams in the upper catchment, which serve irrigation, industrial and municipal water demands. Hence, the increasing water demand for domestic use of Pune's growing population competes with growing energy and 
irrigation water demands. The spatial distribution of land use in the catchment area strongly depends on hydrologic and topographic factors [29]. Changes in land use, however, also affect the water balance. An assessment of land use changes between 1989 and 2009 shows that agricultural areas increased $(+4 \%)$, leading to an increased irrigation water demand [10] (Figure 3). Future land use model predictions until 2028 indicate that the ongoing urbanization $(+8 \%)$ leads to a decrease of agricultural areas $(-4 \%)$ [16], whereas in the past the loss of agricultural land due to urbanization was compensated by a relocation of agriculture to more remote areas in the catchment [10]. However, this might not necessarily result in a lower irrigation demand in the future, as the loss of agricultural area might be compensated by an intensification of management practices on the remaining agricultural fields. Moreover, an assessment of future climate change impacts indicates that the storage capacity of the reservoirs is more frequently not met during the rainy season [14]. In addition, extreme dry years can aggravate the effects of land use change on water resources in the future [16]. Therefore, climate change and land use change may further exacerbate the competition for the limited water resources in the catchment.

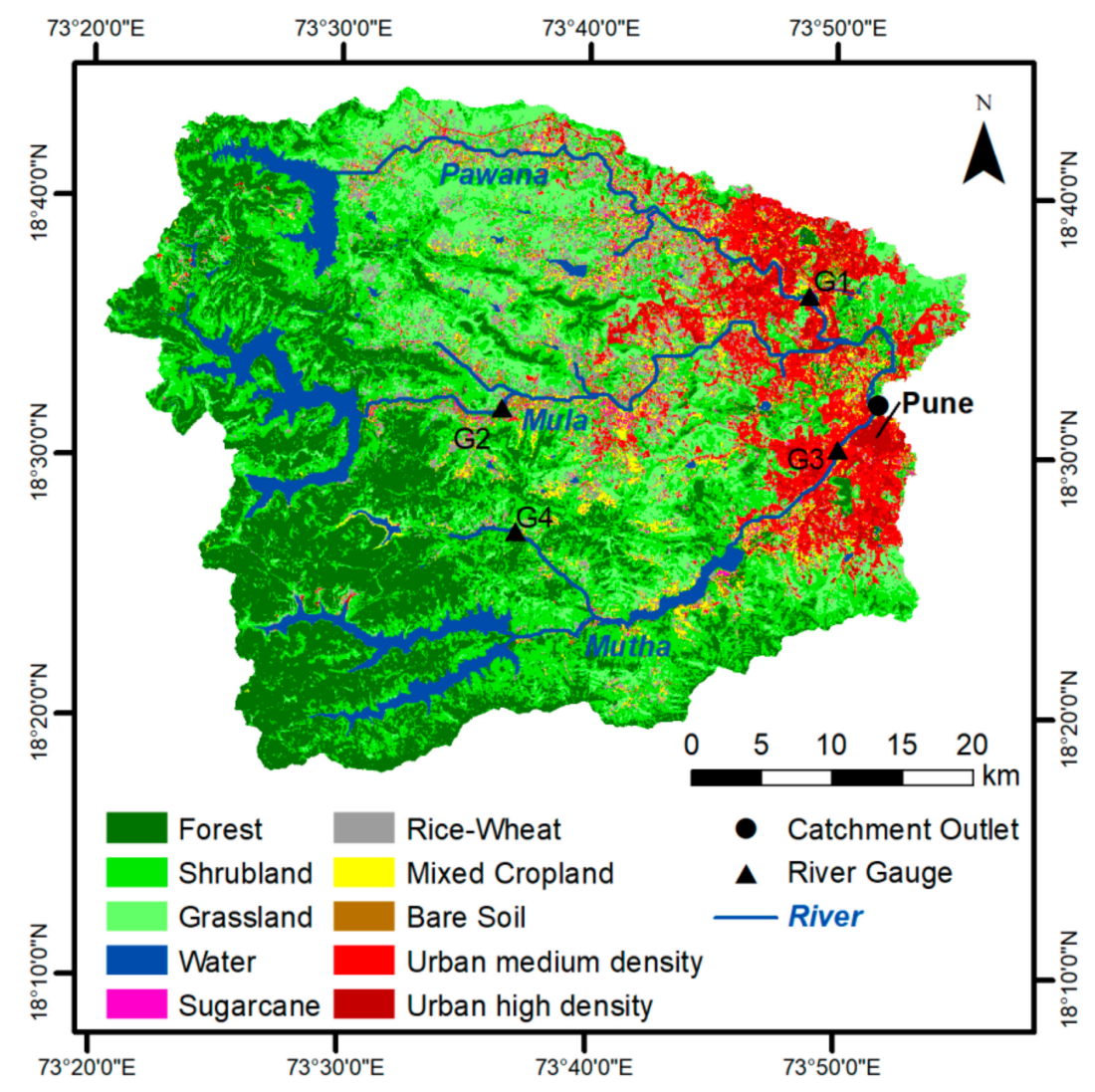

Figure 3. Land use of the cropping year 2009/10 in the Mula and Mutha Rivers Catchment upstream of Pune.

A map of the green areas in the city (Figure 4) shows that the area under the various categories of greens in 2013 covered agriculture land occupies about $17.2 \%\left(43 \mathrm{~km}^{2}\right)$, grassland $13.2 \%\left(33 \mathrm{~km}^{2}\right)$, woodland $7.3 \%\left(18.2 \mathrm{~km}^{2}\right)$ and shrub land 3\% $\left(7.5 \mathrm{~km}^{2}\right)$. During 1992 to 2001, Pune witnessed a loss of about $18 \mathrm{~km}^{2}$ green spaces areas due to a conversion into residential or traffic use (Figure 5). Agricultural land $\left(5.8 \mathrm{~km}^{2}\right)$ and grassland $\left(6.5 \mathrm{~km}^{2}\right)$ are the major green space categories that were converted to built-up areas during 1992 to 2001. However, the rapid urbanization of Pune during the period of 2001 to 2013 led to massive conversion of $52.6 \mathrm{~km}^{2}$ green space area into built-up land use (Figure 5) of which $33.9 \mathrm{~km}^{2}$ were grasslands and $15.9 \mathrm{~km}^{2}$ were agriculture land [18]. 


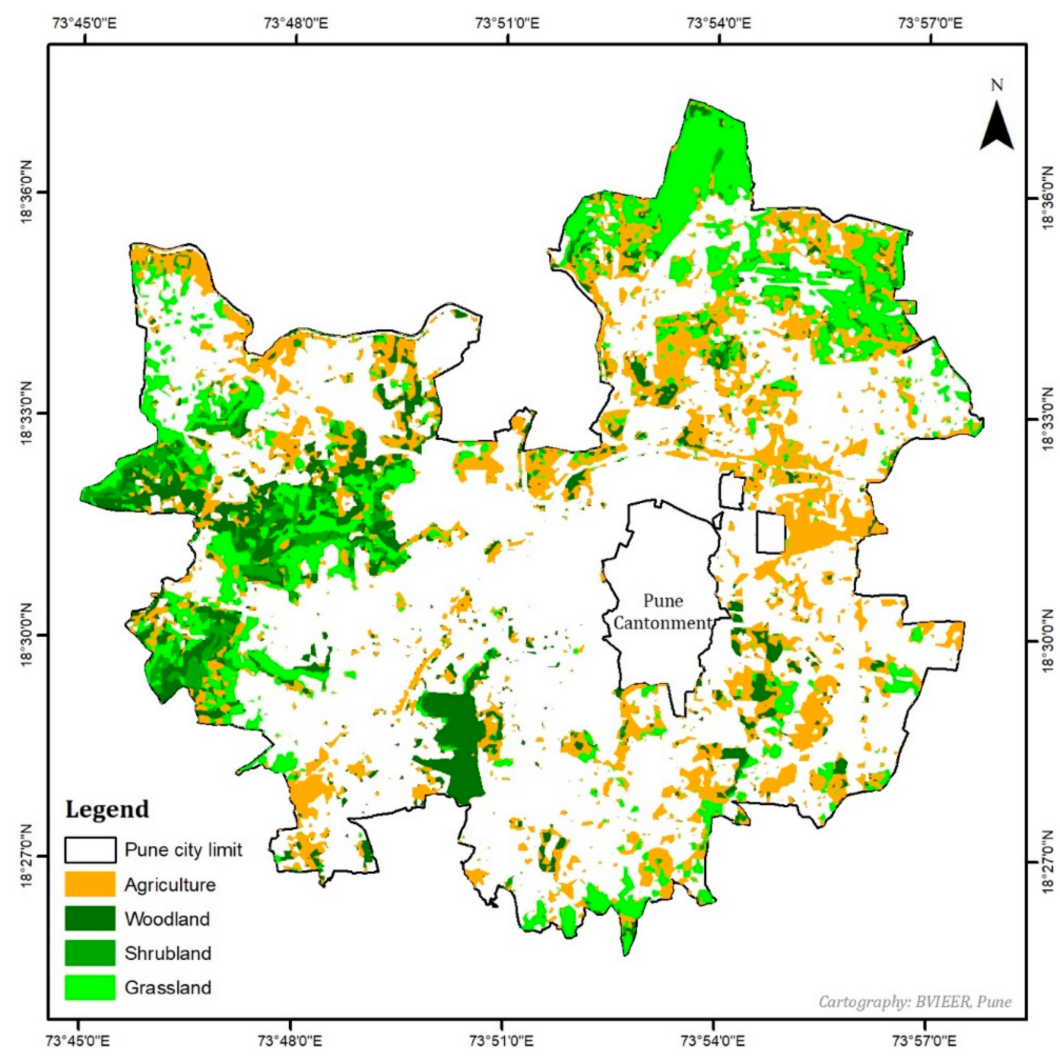

Figure 4. Green spaces in Pune 2013.

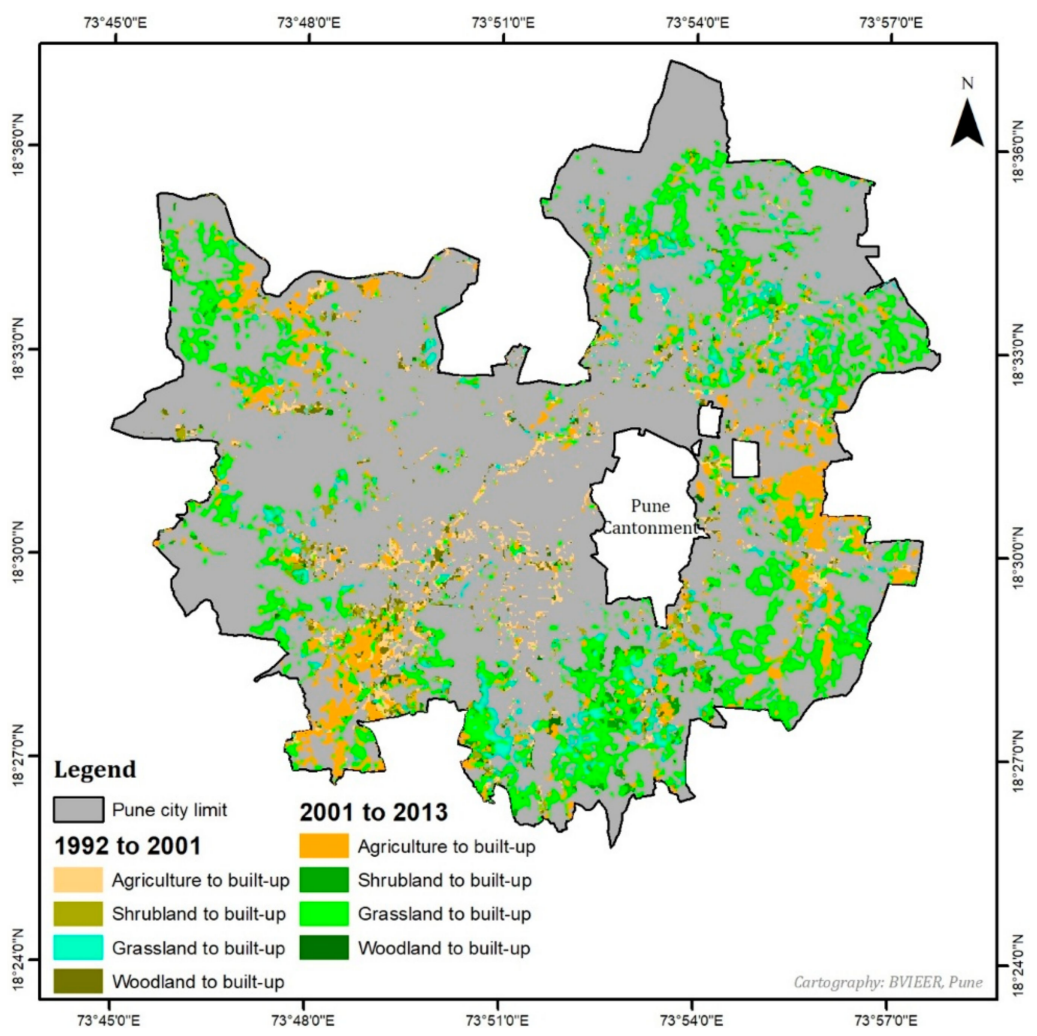

Figure 5. Loss of green spaces in Pune 2001-2013. 
The burgeoning population has placed huge demands on land for infrastructure and residential projects bringing about conversion of agricultural lands and grasslands into residential complexes and information technology parks. Encroachment of hill slopes and river beds by informal settlements is also a result of migration of the poor from the nearby villages and other drought prone regions of the state. Exotic plantations due to city beautifying approaches are also changing the nature of the green cover by reducing the local biodiversity and thus leading to local extinction [30-33]. The changed nature of green cover and housing has already resulted in the drastic decline e.g., of the common house sparrow once seen commonly across the city.

\subsection{Socio-Economic Conditions}

The city's growth and especially the large in-migration has changed Pune's social fabric significantly. However, basic indicators at first glance seem to tell a success story: The literacy rate in the city was among the highest in India, at $89.6 \%$ [4]. The per capita net domestic product for the whole district (figures for the city/the urban agglomeration are not available) in the financial year 2013-2014 reached 171,636 INR (2.867US\$ as of 31 March 2014). This is significantly higher than the average for the State of Maharashtra (117,091 INR; 1955.98US\$ as of 31 March 2014) and almost as high as the state's financial hub Mumbai (188,739 INR; 3152.85US\$ as of 31 March 2014) ([34], p. 32f.).

However, wealth is distributed unevenly in the city and social disparities can be observed along two fault lines, namely along classes and caste groups. An analysis of the social mobility in Pune with reference to the caste background found that 'it is not possible to plot the class map of India without integrating the caste dimension' ([35], p. 69). This shows that intergenerational occupational upward mobility is related to the caste, though the urban setting moderates the limiting factors for upward mobility and opens up new opportunities. However, this study also indicates that social fragmentation is increasing: The share of poor and very poor earners increased (2007) compared to an earlier sample (2000) from $24 \%$ to $27 \%$, while the share of the upper and upper middle incomes increased from $26 \%$ to $29 \%$ [35]. Sidhwani shows in an analysis of census data that in Pune, access to basic services like in-house drinking water and in-house latrines is strongly determined by caste background-and this connection is stronger than in India's other ten largest cities [36].

The increasing social polarization is reflected also in the city fabric. While on the one hand the number of people residing in gated communities is rising, the number of slum dwellers is also increasing. Approximately $36 \%$ of the population is living in 486 slum areas. Out of these, $55 \%$ of slum households have in-house toilet facilities and $90 \%$ have electricity connection [37]. One third of slums are on mixed ownership land, which makes slum rehabilitation more difficult [37]. Overall, the living conditions in slums vary considerably, depending on their status (formal/informal) and in how far NGOs, CBOs and government facilities (e.g., Anganwadis) are involved and committed to improving the local living conditions.

At the same time, prestigious housing projects are constructed on a large scale in the legal form of so-called townships. Besides housing, they offer business opportunities and access to infrastructure, which (by law) has to be significantly better than in the rest of the city, e.g., with $24 / 7$ provision of electricity and water. The largest and most prestigious of these townships, Magarpatta City, is an interesting case, as it attracted attention well beyond the city limits. The project was developed by a local farmers' community and described as 'self-sustainable ecological habitat' [38]. This walled settlement provides essential infrastructure services like schools, health care and recreational facilities. According to PMC [24], six townships with up to 15,000 housing units already existed in Pune in 2012 and 25 more were in the planning process. Besides slums on the one hand and the exclusive townships on the other, there are co-operative housing societies, which provide housing for the middle and upper middle classes, usually in the form of multi-storey houses in walled compounds and the traditional houses in the city center, the 'wadas' and the 'chawls'.

The socio-economic disparities in Pune occur in close spatial proximity. Figure 6 shows the standard of living index of six neighborhoods within the city (location: Figure 1). These have 
been chosen as examples for different socio-economic groups residing in different parts of the city representing different phases of city development. Two neighborhoods are situated in the city center (area A), with more or less long-established population; two neighborhoods are situated in the former British city extension (Area B), representing on the one hand the established upper middle class (residing in old bungalows and co-operative housing societies of high standard) and on the other hand temporary migrants; two neighborhoods are situated in an area which is among the most recent urban extensions of the city (area C) [19,39]. The standard of living index, developed by the International Institute for Population Sciences [40], assesses the living standard of a household through the availability of assets (e.g., car, fridge, mobile phone) and accessibility to basic infrastructure (e.g., access to drinking water and toilet). The index was slightly modified: agricultural assets (e.g., tractor) and house ownership were not included. Figure 6 shows a socio-economic gradient from the two upper middle class areas to the unregistered slum area. In the younger declared slums in Kondhwa (area C), signs of an upward mobility are visible. Within the middle class there is a clear distinction between the established lower middle class in the old city center; the young professionals in the new housing societies in Kondhwa and the still somewhat traditional oriented neighborhood in Koregaon Park.

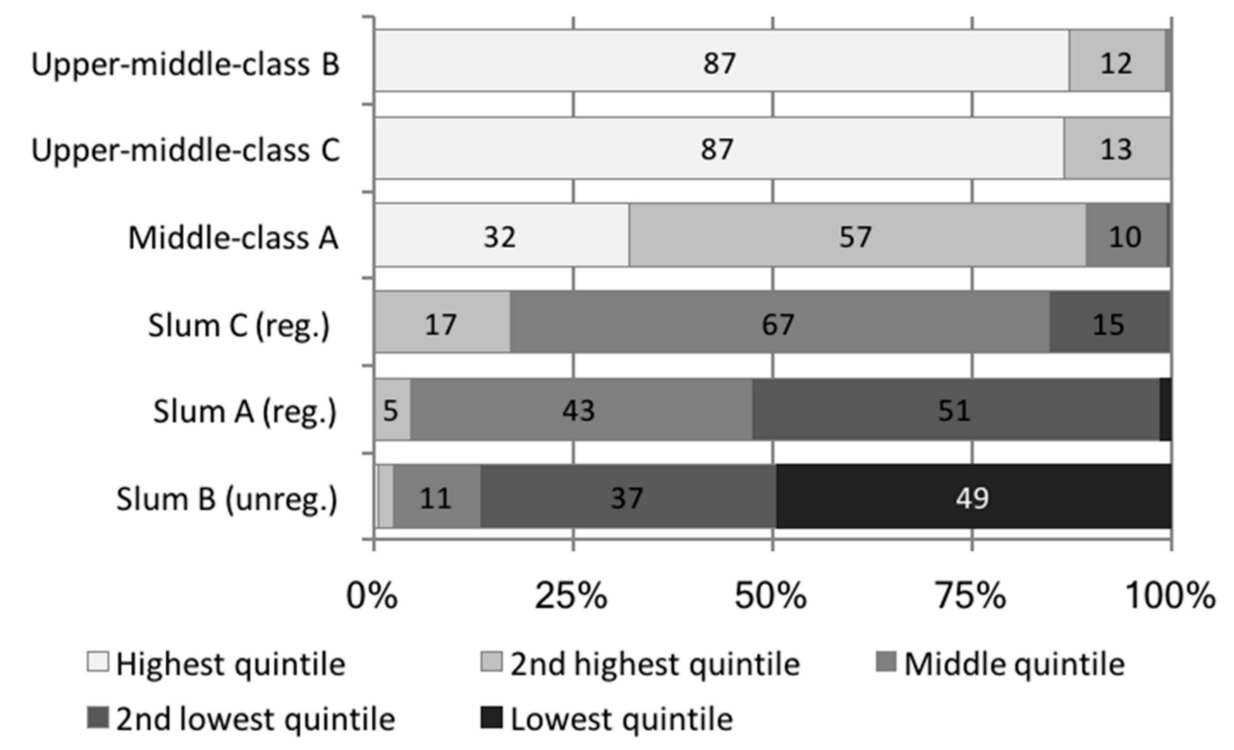

Figure 6. Standard of living index for six neighborhoods in Pune (source: survey Butsch/Kroll 2008/09 and 2009/10) [39].

The findings of the six neighborhoods illustrate different living conditions between, but also within the neighborhoods. Furthermore, multiple functional connections between the different socio-economic groups exist, especially between neighboring slum- and non-slum areas. In Kondhwa (area C) for example, one of the slums started as an informal settlement of construction workers for a neighboring housing society. However, 25 years later, a large share of the slum's females work as maids in the same housing societies and the men work, e.g., as rickshaw drivers, both serving the middle classes as cheap work force.

\subsection{Economic Development}

The population development and the increasing socioeconomic polarization are linked to the economic development of the city. The first industrial production unit in Pune, an ammunition factory, was built in 1869. In 1885, the Deccan Paper Mill, in 1888, a copper and brassware factory and in 1893, a textile mill were founded [41]. In the 1940s, an increase in employment opportunities attracted migrants due to intensified armament production during World War II [23]. Further, Pune enjoyed the 
reputation as a production site for bicycles and food processing [42]. In 1946, industrial diversification started with the establishment of Kirloskar Oil Engines, followed by companies of the automotive and the chemical sector like Hindustan Antibiotics, Cooper Engineering, Buckau Wolf, K.S.S. Pumps Bajaj Auto Works, Bajaj Tempo, Garware Nylons or Ruston and Hornsby [41].

In 1960, the newly founded Maharashtra Industrial Development Corporation started to develop a new industrial estate north of Pune towards Mumbai. Around the two villages Pimpri and Chinchwad, land was purchased and new industries were attracted. In the cluster, which was meant to establish a second industrial center in Maharashtra besides Mumbai, mainly automobile industries and pharmaceutical industries were established. Among the first in this was the Swedish multinational SKF bearings, followed by TELCO (now Tata Motors), and several other multinational joint ventures like Alfa Laval, Atlas Copco, Sandvik Asia, Kinetic Honda or Mahindra, making Pune a center of the two-wheeler and car production in India as well as other engineering products. This cluster attracted foreign companies like Mercedes Benz (1996) and Volkswagen (2009) in the context of the opening policy of the 1990s.

An important location factor for these partly labour-and partly technology-intensive industries is the presence of higher and vocational educational facilities in Pune. Currently, there are nine universities and more than 100 facilities of higher education in Pune ([24], p. 38); the first established was the College of Engineering (1854) followed by Ferguson College (1885). The availability of well-trained professionals also led to the recent establishment of Pune as an IT hub. In the 1990s, the establishment of IT parks was promoted by the central government through the software technology parks of India (STPI) scheme [43]. Four special IT parks were set up in 1999 and started to attract companies of international importance like Infosys (which was founded in Pune), IBM and Accenture.

Pune's formal economy has a robust base. The orientation towards knowledge-based sectors (IT) in combination with manufacturing and production of food and pharmaceuticals offers future proof jobs for different skills and the city's economy does not depend on one branch. However, as in many cities of the Global South, the informal economy is for large parts of the population the most relevant source of income. According to Kumar, quoting Census 2011 figures (data not freely available), the workforce participation rate in the Pune Urban Agglomeration stood at 38.8\% [44]. This relatively low figure indicates that there is a large number of persons working in the informal sector. Informal occupations come along with a large number of disadvantages like lack of revenue for the state, of security and of binding standards. However, the informal sector also creates income for a majority of the population, it is shaped by highly dynamic, often creative and solution oriented processes and informal institutions contribute to the efficiency of the city's economy $[45,46]$.

\subsection{Politics and Planning}

Cities in India are primary engines of economic and demographic growth. However, they are challenged by informality, poor infrastructure and inadequate planning and governance [46]and Pune is no exception. The city is developed under the twenty-year Development Plan (DP) which was prepared by the state government due to inadequate expertise at the level of the municipal corporation. The DP was prepared in accordance with the Maharashtra Regional and Town Planning Act (MRTP) of 1966, according to which the municipal bodies in Maharashtra must prepare plans for areas under their jurisdiction at a regular interval of twenty years. The implementers (in this case the executive headed by the Commissioner) and the legislative (formed of elected members) have varied terms ranging from three years for the former to five years for the latter. Thus, over the period of twenty years, no single individual can be held responsible for the implementation of the DP and the focus always is on implementation of short-term plans enabling them to take credit for their actions. The politics of planning is more important than the technical aspects. The implementation depends on several factors: (1) the relationships between the state government and the municipal body, (2) the relationships between the political and bureaucratic wings of the municipal corporation, (3) the support of the politicians at the local and state level, and (4) the support from citizens' groups. While the 
Indian planning legislation encourages the partnership of its citizens by making it obligatory for the municipal corporation to invite objections from the public, the lack of transparency often subverts this process. However, in the recent past the Pune Municipal Corporation encourages participation of its citizens in the design and implementation, thus subverting the hidden agenda of politicians as well as other stakeholders [47].

The DPs prepared by PMC prioritize water and sewage, transport, health and social infrastructure. Protecting the biodiversity, hills and water bodies all integral to Pune was not included in the plan until the recent DP 2007.

Two examples highlight the informality that exists in planning. First, the notification of the 'Biodiversity Parks'. The theory of collective benefits, mobilization of public support and strong stakeholder partnerships (media-NGO) as well as similar political parties in the state and the PMC helped the final notification of biodiversity parks. While the hills were designated as reserved spaces to act as the lungs of the city in the $1987 \mathrm{DP}$ (at a rate of 0.24 ha per 1000 people), it is only the above combination that brought this aspect to fruition as late as $2015[48,49]$. The second is the existence of slums (informal housing) (cf. Section 4.2). Since a large share of them is not notified, they are seen as illegal and the PMC does not have any obligation to provide basic services to these sites. Yet, the slum dwellers also develop negotiation power. Since these informal settlements are important voting banks, politicians often connive to get these notified-if no other (more prestigious) projects demand the same space.

Another example for new pathways in the planning process is the development of the Magarpatta City Township. This new settlement for 100,000 people was built as a city within a city through public private partnerships. The basis was the pooling of land by 120 farming families for this new urban development pattern to enable citizens to escape from the informalities of the present city development process. This model has been replicated in Amonara, a similar township and Nanded City, a venture similar to Magarpatta [50].

It is no surprise that given the high degree of informality, unstructured processes and duplication of responsibilities, Pune as a city lags behind in the development of infrastructure and other services needed to serve its large urban population in its quest to be a 'world class city'. Thus, in the face of increasing urbanization and a growing backlog in infrastructure investments, the Jawaharlal Nehru Urban Renewal Mission (JNNURM) was launched in 2005. The key goal was to develop cities as engines of economic growth by incentivizing urban reforms at state and city level through the provision of grants to fast track infrastructure development. The Mission follows on from the 14th Constitutional Amendment Act, 1992 that strengthened decentralization of the management of cities under urban local bodies (ULB). The two phases over which JNNURM was implemented were only moderately successful due to its ineffective urban land acquisition processes and funding delays. The performance audit of the Mission by the Comptroller and Auditor General (CAG), showed huge deficiencies [51]. The CAG report stated that only 22 of the 1517 projects approved in 2005 and 231 of 1298 approved in 2011 were completed as of 31 March 2011. While housing and urban infrastructure projects were implemented, the process of bringing in institutional, financial and governance structures to make the ULBs efficient, accountable and transparent was not achieved [51].

This was thus the genesis of the Smart City Mission (SCM) that is presently being implemented. The 'Smart City' phase was introduced by the present central government in 2016. While the definition of 'smart cities' is ambiguous world over [52], the goal of the Smart City Mission in India is to create cities with smart physical, social, institutional and economic infrastructure including clean technology use, widespread information and communication technology reliance, financing via public private partnerships and private sector investments, improved citizen consultation and 'smart' or e-governance initiatives.

Pune was one of the ninety-eight cities to be selected in the first phase of the SCM. Plans require following an area-based approach, such that certain areas within a city would be the focus of being made 'smart', either by upgrading areas in existing cities through retrofitting or redevelopment or 
developing new green spaces of more than 250 acres within the geographic limits of the ULB or Urban Development Authority (UDA). Moreover, cities are required to implement a pan-city approach to improve city-wide infrastructure in one or more sectors. The SCM guidelines call for extensive citizen and stakeholder consultation.

In Pune, the development began in late 2015 with the help of consultancy or 'hand-holding' agencies to assist in the conceptualization and development of area-based and pan-city projects. For Pune a 'Special Purpose Vehicle' (SPV) has been instituted to oversee and implement the smart city plan. The SPV is a pre-requisite for disbursement of money announced by the Central government and is a 50:50 partnership between the State government and Pune Municipal Corporation with 15 board members.

A smart city strategy for Pune was developed in 2015. The municipal corporation claims to have involved $50 \%$ of the citizens in the development of this strategy [8]. The strategy is guided by the vision: 'Leveraging its rich cultural and natural heritage, strong human capital and strong business environment as key strengths, Pune aspires to become the most livable city in India by solving its core infrastructure issues in a 'future proof' way and by making its neighborhoods beautiful, clean, green and livable'. Several projects were developed, most of these aim at improving infrastructure (traffic, public transport, water) and small scale provision of services (3 multispecialty hospitals, 3 schools, 76 public toilets), redevelopment of one slum-pocket (improvement of 500 slum households-a figure that has to be judged against the presence of almost 500 slum pockets) and 'typical' 'smart city' features, like Wi-Fi access in public areas and 'smart parking' (for 750 cars-which again has to be assessed against the city's enormous traffic problems).

\subsection{Two Exemplary Fields of Action: Health and Waste}

Informality and shortfalls in planning affect the livelihoods of urban dwellers in many ways. Urban health and waste management are two fields in which unsustainable developments have direct impacts on the health and the quality of life.

The health of Pune's population is affected by changing living conditions in the city, like socio-economic diversification, lack of infrastructure provisioning, changing lifestyles, liberalization and economization of the urban health system. These factors interact in a complex manner. On the one hand, rapid urbanization results in a degradation of the urban environment: traffic, industries and use of fossil fuels cause high air pollution, lack of treatment facilities for wastewater results in an exposure to contaminated water and the insufficient treatment facilities for solid waste pose multiple health hazards [53]. The exposure to these environmental factors follows a steep socio-economic gradient, with the poorer having less opportunities to protect themselves. On the other hand, changing lifestyle patterns and changing dietary patterns can result in malnutrition, obesity and rapidly increasing incidence rates of so-called civilization diseases like diabetes and hypertension-in all strata of the society [39,54]. At the same time, infectious diseases such as malaria, dengue and tuberculosis still pose a health threat [54].

The liberalization of the Indian economy also affected the health care system. In Pune, a large number of private health care facilities emerged especially since the year 2000 and most of the traditional private facilities have grown in size and increased their services. Therefore, medical treatment comparable to international standards is available in several health care facilities. The public health care services, once intended to serve as the regular source of care in India, has not been able to keep pace with the city's growth. Because of this and the shortfalls in the provision of consumables, public facilities—-though having highly qualified personnel—are not able to deliver adequate treatment. The private providers stepped into this gap but often have charges beyond the economic capacity of large sections of the society. Additionally, some of the treatment procedures like over-diagnosis, over-treatment or inadequate medication have to be addressed as unethical. In this situation, access to health care services - understood as the utilization of adequate services—is difficult for many Puneites [55]. 
From a sustainability perspective, the lack of investment in public health care facilities and the lack of regulation of the private health care sector aggravates the existing social polarization, since out of pocket payment affect socio-economically weak households strongly and often result in impoverishment. The health system of the city is at present not suited for the health challenges (especially the changing burden of diseases) and therefore contributes to socially unsustainable developments. The health problems of Pune's population are therefore linked to the social dimension of sustainability and the ecological one, since health problems are arising from the environmental degradation.

In addition, waste management is affected by changing lifestyles in Pune. Together with the increasing population they are leading to rising quantities and qualities of municipal garbage (e.g., packaging waste, electronic waste), causing high environmental costs. Electronic waste, which has amounted to 10,000 tons per year in the Pune urban agglomeration [55], causes high environmental damage if not properly disposed and poses health risks. Around 1600 tons of municipal solid waste are generated in Pune on a daily basis, varying from 350 to 750 grams per person per day [24]. The PMC estimates that the garbage amount could quadruple between 2012 and 2041 [24]. The garbage consists of $53 \%$ organic, compostable material and $47 \%$ inorganic material, of which around half is recyclable (e.g., glass, paper, plastic) [55].

The city's waste management system has undergone enormous transitions in the last 15 years in order to cope with the increasing challenges and to reorganize the system according to national legislation. For household waste, which accounts for up to $70 \%$ of the generated waste per day in Pune [24], the system has been changed from a bring system (where households had to bring their waste to containers placed in public places) to a doorstep collection system in order to increase the collection efficiency, the environmental hygiene, the segregation at source and recycling rate. The doorstep collection has been outsourced to $\mathrm{SWaCH}$, a cooperative for Solid Waste Collection and Handling, which emerged from the trade union of waste pickers (KKPKP) and was founded in 2007 [56-58]. Segregation at source could be improved from $24 \%$ (2012) to 57\% (2015), waste collection efficiency from $71 \%$ to $90 \%$ [59]. The women collect around $600 \mathrm{t}$ of garbage every day, of which $130 \mathrm{t}$ of organic waste is composted and $150 \mathrm{t}$ is recycled [42]. Furthermore, the PMC has reorganized the processing of organic waste through decentralized processing units in housing societies and public and private facilities in the municipal area. The landfill Urali Devachi, located $20 \mathrm{~km}$ outside of Pune, has been sanitized [60].

Though the transformation of Pune's waste management system is not yet completed, several important intermediate goals have been achieved: From an ecological point of view, an increasing amount of recyclable and organic waste gets reused and processed. This also effectively saves costs for transport and disposal. From a socio-economic point of view, the integration of waste pickers not only led to a recognition of their contribution to the urban economy, it also combats poverty through consistent and enhanced work opportunities.

\section{Discussion}

In the first issue of the journal City, David Harvey wrote: 'The 20th century has been, then, the century of urbanisation. The future of the most of humanity now lies, for the first time in history, fundamentally in urbanizing areas. The qualities of urban living in the 21st century will define the qualities of civilization itself' ([61], p. 403, italics in original). It is the fast-growing agglomerations like Pune that will define in Harvey's words then, how we will be living and what our societies will look like in future. As shown above, Pune has quite a solid base for development, as the educational base is comparatively good and the economy (service sector, manufacturing) is relatively robust and quite diverse.

However, overall Pune's development is far from sustainable. The ecological resources are overexploited, and necessary protection, e.g., of water reservoirs or green spaces, does not take place in the city. Even worse is the situation in the periurban areas surrounding the city, which are already heavily affected by urbanization processes $[10,16]$. The pattern of urban growth in Pune is 
of three types: core infilling, ribbon development and scatter development [18]. Administratively, periurban areas are mostly governed by gram panchayats (rural councils) that are financially and institutionally ill-equipped to deal with the new realities in periurban areas. The provision of nagar panchayats (Notified Area Council) in the 74th amendment act in India in 1992, created especially for transitional spaces like the periurban areas, has not been implemented on the ground for the most part [62]. This governance gap leads to haphazard urbanization processes. In the case of Pune, the periurban areas are affected by resource intensive and unsustainable growth patterns like scattered growth and ribbon development [18]. Planning for the fringe and the periurban is generally relegated to the background and the focus is on core city development. Regularization of grown structures and provisions of services becomes difficult once the fringes are incorporated into the city. However, since 2008 the state government enforces Pune's development control (DC) rules to areas up to $10 \mathrm{~km}$ from the civic limits. In 2015, the Pune Metropolitan Regional Development Authority was constituted ensuring that 100 villages will have a uniform development plan. Yet this plan has to be based on a comprehensive vision, building upon multi-stakeholder discussions; this seems more than necessary in order to guide the future urban development beyond contradicting vested interests.

It has to be stated that the ecosystem services of the city are endangered by the overexploitation of resources, especially in the city's periurban surroundings. Thus, there is an urgent need for the development of effective governance structures, crossing administrative boundaries and providing plans on the regional scale, as demanded also in the New Urban Agenda are urgently needed.

In the social dimension, the city faces an ongoing fragmentation, with some residents involved in high-skilled occupation and following resource intensive lifestyles, while others are disconnected from economic growth-with severe adverse effects in different areas of life, e.g., their housing conditions, health, their ability to provide education for their children. Planned measures for social housing, slum upgrading and provision of public health infrastructure are always part of new strategies, like the 'smart city' mission-yet, their impact has been marginal in wake of the ever-increasing slum population of the city. These informal settlements are the most obvious physical manifestation of social disparities, which can be found along class and caste boundaries in Pune. In India, urbanization has led to the emergence of a complex social matrix in which traditional and modern values influence the societal stratification. Social inclusion beyond the provision of adequate housing (which is an urgent need indeed) is an issue which so far has hardly been addressed in the Indian society. Although India has a vivid civil society, its cities are far from the (utopian?) vision framed for the sustainable city in the New Urban Agenda. New strategies for a more inclusive development need to be developed urgently addressing social fault lines and also fault lines between different communities.

Economically, Pune is a beacon for development. Especially the city's diversified economic structure is quite robust. Though, the high share of informal employment without any job security and employment in low-income formal sector has to be addressed as problematic. The transformation from an informal to a formal economy is possible, as the example of the waste pickers, described in Section 4.5, shows. This transformation does not only bring security for those employed but also generates revenue for the state, which can be invested in infrastructure and services. Yet, as many other problems this is one which cannot be solved comprehensively at the local level.

Planning, though considered to be a process of providing physical structures, does no longer fulfil the requirements $[63,64]$. Multiple actors such as businesses, politicians, commercial developers, activists, etc. play an important role in this process, where they often seek to further their respective interests. The preparedness of stakeholders to partake in balancing collective versus individual benefits, the availability of resources, the levels of literacy and the transparency of plans decide upon the trajectory of the planning implementation [65]. Currently, under the 'smart city' programme, Pune follows an interesting approach which looks at specific problems in different neighborhoods. Though, several of the small projects could be criticized for their orientation towards technology and thus only being of interest for the wealthier strata of society. Therefore, it is important that sustainability programs address the different needs of socio-economic groups within the city, reaching from basic 
infrastructure provision to city beautification. Diverse approaches, both planned and spontaneous, arising from the interesting medley of interaction with stakeholders have been used. These include developing townships through public private partnerships, to retrofitting existing cities, to renewing slum areas, to conserving urban biodiversity and devising solutions for urban mobility. The model for area-based development could be implemented in the transforming periurban areas, too. The areas around Pune are more or less subject to spontaneous development [66], often driven by financially potent developers-without considering sustainability or 'smart' plans for growth.

Another aspect, which was partially addressed by the 'Smart Cities Mission' is participation in planning. The first steps taken here are promising, though levels of participation in planning definitely need to be increased. Decision makers should have the courage to try new forms and models of participation and develop Pune-specific solutions for sustainable urban development.

This paper brings together different perspectives on urban growth-related challenges for sustainability, ranging from natural sciences to social sciences perspectives. The holistic view of the different dimensions of sustainability is essential to map a pathway to sustainability. Describing and analyzing the different methodological and contextual perspectives is a necessary first step to diagnose cause and effect relationships and to understand the inherent processes. However, 'smart' management of urban growth requires predictive capabilities which must be based on solid observations, understanding of cause and effect relationships as well as on knowledge of the rules, laws and institutions structuring social, economic and environmental processes. Thus, a closer integration of the different disciplinary approaches, methods, diagnosis and modelling tools is needed to identify better management options, to understand natural and societal development and to acknowledge processes (e.g., informal development), which are beyond our immediate control and management abilities. All these processes occur in a spatio-temporal context and against a background of natural conditions and a given set of social norms, rules and institutions. Thus, the set of tools needed to help developing more sustainable approaches to manage urban growth need to address this complexity. Integrating computer-based numerical models, measurements and observations derived from the different kinds of sensors (e.g., satellites, gauges, smartphones), with data from quantitative and qualitative social science research on human behavior, perceptions, values or intentions, remains a huge challenge for planners. Despite the challenges, cross-disciplinary cooperation and integration is the most promising pathway to achieve more sustainable development and to move from reactive measures to predictive management.

\section{Conclusions}

Using the example of Pune, it was shown that even prospering cities in quickly urbanizing low middle-income countries face severe challenges regarding sustainable development. These arise from several structural factors, e.g., given planning laws, an environment favoring informal developments and population pressure. Several factors influencing the city's development trajectory are not influenced on the local level. Thus, urban development has to be regarded as the product of processes on different scales, ranging from the international level (e.g., through visions laid out in documents like the report of the World Commission on Environment and Development, or the Habitat II- and Habitat III documents) via the national level (planning of infrastructural projects like the golden quadrangle in India or policies like the 'Urban Renewal Mission' or the 'Smart City Mission') to the regional and local level. Sustainable urban development cannot be achieved by actions on city levels alone. India needs to design a sound urbanization strategy to steer its urban growth, particularly against the background that an additional 394 million urban dwellers are expected between 2015 and 2050 [26]. This requires further empowerment of urban local bodies who need more competencies and more financial autonomy. Another demand is the establishment of powerful regional planning authorities who not only develop integrated plans for urban agglomerations and their periurban surroundings but also have the power to actually enforce their establishment. This would require a paradigm shift in the thinking of local politicians who are too often interested in unsustainable developments, e.g., exclusive 
new housing in eco-sensitive areas without any social inclusion (like the newly developed destination Lavasa in the Western Ghats). Too often, local politicians and administrations still form coalitions to keep the 'growth machine' [67] running.

In the overview of case studies, the three dimensions of sustainability were addressed. In the ecological dimension, the fast-growing agglomeration is depending on ecosystem services provided by the hinterland and within the city; yet the resources are not adequately protected (urban green) and/or overused (water). Moreover, land use and climate changes may exacerbate this situation in the future. In the economic dimension, the robust formal growth is paralleled by a growth of informal occupations, which adds to the city's creativity and flexibility but leaves large sections of the society also in insecurity. As shown in the section on the social dimension, there are sharp social differences in the city. However, there are various connections between the different socio-economic groups residing in spatial proximity. But social inequalities have further implications, e.g., adverse effects for health—especially for the socio-economic weaker population, as discussed-and have therefore to be addressed as unjust.

The planning regime for Pune in many cases fails due to several structural reasons and conflicting interests. New ways, like special purpose vehicles, are installed to overcome blockades and move forward in specific sectors. As the example from the waste management sector shows, changes driven by civil society can result in improved governance. Nevertheless, a powerful holistic planning approach currently exists on paper only. Especially for the transformation of the urban fringe- the city to be-windows of opportunity have to be used to shape a sustainable city of tomorrow. Sound planning, multi-level governance frameworks and the agency of local administrations to enforce plans are needed to create livable habitats in the future: In the core areas, heritage and the historically grown structures need to be protected and modernized with care, while in newly developing areas smart ideas are needed to prevent social segregation and unsustainable growth.

Several approaches towards sustainable development can be found in Pune, some being stimulated by top-down policies, some by bottom-up processes. Yet, an overarching strategy combining the bits and pieces of a pathway for a transition to sustainability does not exist. What is needed, is on the one hand a strategy for a 'smart' development that makes best use of the opportunities within the given framework and on the other hand political agency to change the framework itself. Pune's growth has to be managed holistically, which means that instead of sectoral or small-scale approaches, a true vision for the agglomeration has to be developed. The development expected in the next years has to become more integrative, avoiding walled enclaves for few, but creating decent housing space also for the less affluent and allowing them to leave informality (of housing and of living). Finally, development has to become truly participative; ideas from different societal groups about Pune's future should be brought together to develop a sustainable, locally adjusted sustainability pathway as an alternative to the stereotype of the 'world class city' narrative.

Our analysis shows, that even a prosperous city like Pune suffers from its embedding in a weak institutional framework. Thus, for directing the growth of India's cities towards more sustainable trajectories a fundamental shift is needed, using the vision of the New Urban Agenda as a guideline. We would like to highlight three central recommendations: (1) India needs a sustainable urbanization strategy, which goes beyond sectoral issues (like the 'Smart City Mission') but develops a strong comprehensive vision for India's urban future-rooted in India's society. Along with this vision regional planning authorities and local authorities need to be empowered to develop and implement locally adjusted sustainability strategies. This requires increasing the financial power of local authorities. (2) Comprehensive strategies for a more socially inclusive development are needed. These have to go far beyond the provision of slum rehabilitation schemes-through the provision of decent living spaces for all, ideally through in-situ upgrading. As of now, there are hardly any policies beyond the housing sector, which address social inclusion. Given the complexity of India's society, which is increased through urbanization, measures to address this issue are urgently needed. (3) There is an urgent need to reconsider the relation and connection between the urban and 
periurban areas. Strengthening the exchange relations on a regional level can result in more sustainable consumption patterns and safeguard the provision of important ecosystem services.

Acknowledgments: The authors are grateful to IMD Pune, Water Resources Department Nashik, Khadakwasla; Irrigation Division Pune, Groundwater Department Pune, Department of Agriculture Pune, and NRSC Hyderabad for supplying environmental data, good cooperation and discussions, and various departments of the Pune municipal Corporation for support of different projects, jointly carried out by BVIEER and University of Cologne.

Author Contributions: Carsten Butsch was responsible for the overall conception of the article; he designed and carried out research on urban developments in Pune and access to health care services, he drafted the introduction, the section on socio-economic development, economic development, health, the discussion and the conclusion; Shamita Kumar was responsible for the overall conception of the article; she drafted the section on the historical development, land and water resources and about politics and planning, she carried out research on land transformations and urban growth and contributed to the discussion and the conclusion; Paul D. Wagner carried out research on hydrologic modelling and land use and climate change impacts on the water resources in Pune; he drafted parts of the section on land and water resources and contributed to the discussion and the conclusion; Mareike Kroll carried out research about the epidemiological transition in Pune and about Pune's waste management sector; she drafted parts of the section on health and waste and contributed to the discussion and the conclusion; Lakshmi N. Kantakumar carried out about research about land transformations and urban growth; he contributed to the sections on historic development, land and water resources and the discussion; Erach Bharucha, Karl Schneider and Frauke Kraas acted as principal investigators in projects on urban development, urban health and Pune's hydrology; all three contributed to the overall conception of the article and to the discussion and the conclusion. All authors read and approved the final manuscript.

Conflicts of Interest: The authors declare no conflict of interest.

\section{References}

1. World Commission on Environment and Development. Our Common Future; Oxford University Press: New York, NY, USA, 1987.

2. UKAID (Department for International Development); DFID (Department for International Development). Future Proofing Cities. Risks and Opportunities for Inclusive Urban Growth in Developing Countries; UKAID: London, UK, 2012.

3. United Nations Conference on Housing and Sustainable Urban Development (Habitat III). Draft Outcome Document of the United Nations Conference on Housing and Sustainable Urban Development (Habitat III). Available online: http:/ / habitat3.org/wp-content/uploads/Draft-Outcome-Document-of-Habitat-III-E_ 29556.pdf (accessed on 2 September 2017).

4. Census of India. Pune City Census. 2011. Available online: http://www.census2011.co.in/census/city/375pune.html (accessed on 2 September 2017).

5. Shaw, A. Peri-urban interface of Indian cities: Growth, governance and local initiatives. Econ. Political Wkly. 2005, 40, 129-136.

6. YASHADA (Yashwantrao Chavan Academy of Development Administration). Maharashtra Human Development Report 2012; YASHADA: New Delhi, India, 2014.

7. GoI (Government of India); Ministry of Commerce and Industry. Concept Paper Delhi-Mumbai Industrial Corridor; GoI: New Delhi, India, 2007.

8. Pune Smart City. Pune Smart City Vision. Available online: http://www.punesmartcity.in/?wicket: bookmarkablePage=:Com.SmartCity.Page.Internal.Cityvision (accessed on 2 September 2017).

9. Arnold, J.G.; Srinivasan, R.; Muttiah, R.S.; Williams, J.R. Large area hydrologic modelling and assessment-Part 1: Model development. J. Am. Water Resour. Assoc. 1998, 34, 73-89. [CrossRef]

10. Wagner, P.D.; Kumar, S.; Schneider, K. An assessment of land use change impacts on the water resources of the Mula and Mutha Rivers catchment upstream of Pune, India. Hydrol. Earth Syst. Sci. 2013, 2233-2246. [CrossRef]

11. Wagner, P.D.; Fiener, P.; Schneider, K. Hydrologische Auswirkungen des Globalen Wandels in den Westghats. Geogr. Rundsch. 2015, 67, 48-53.

12. Wagner, P.D.; Kumar, S.; Fiener, P.; Schneider, K. Hydrological Modelling with SWAT in a Monsoon-Driven Environment: Experience from the Western Ghats, India. Trans. ASABE 2011, 54, 1783-1790. [CrossRef]

13. Wagner, P.D.; Fiener, P.; Wilken, F.; Kumar, S.; Schneider, K. Comparison and evaluation of spatial interpolation schemes for daily rainfall in data scarce regions. J. Hydrol. 2012, 464-465. [CrossRef] 
14. Wagner, P.D.; Reichenau, T.G.; Kumar, S.; Schneider, K. Development of a new downscaling method for hydrologic assessment of climate change impacts in data scarce regions and its application in the Western Ghats, India. Reg. Environ. Chang. 2015, 15, 435-447. [CrossRef]

15. Clarke, K.C.; Gaydos, L. Loose-coupling a cellular automaton model and GIS: Longterm urban growth prediction for San Francisco and Washington/Baltimore. Int. J. Geogr. Inf. Sci. 1998, 12, 699-714. [CrossRef] [PubMed]

16. Wagner, P.D.; Murty Bhallamudi, S.; Narasimhan, B.; Kantakumar, L.N.; Sudheer, K.P.; Kumar, S.; Schneider, K.; Fiener, P. Dynamic integration of land use changes in a hydrologic assessment of a rapidly developing Indian catchment. Sci. Total Environ. 2016, 539, 153-164. [CrossRef] [PubMed]

17. Kantakumar, L.N.; Sawant, N.G.; Kumar, S. Forecasting urban growth based on GIS, RS and SLEUTH model in Pune metropolitan area. Int. J. Geomat. Geosci. 2011, 2, 568.

18. Kantakumar, L.N.; Kumar, S.; Schneider, K. Spatiotemporal urban expansion in Pune metropolis, India using remote sensing. Habitat Int. 2016, 51, 11-22. [CrossRef]

19. Kroll, M. Gesundheitliche Disparitäten im Urbanen Indien. Auswirkungen des Sozioökonomischen Status Auf Die Gesundheit in Pune; Steiner: Stuttgart, Germany, 2013.

20. Diddee, J.; Gupta, S. Pune. Queen of the Deccan; Elephant Design: Pune, India, 2003.

21. Krishnamurthy, R.; Mishra, R.; Desouza, K.C. City profile: Pune, India. Cities 2016, 53, 98-109. [CrossRef]

22. PMC (Pune Municipal Corporation). Final Draft City Development Plan Volume I; PMC: Pune, India, 2012.

23. Bapat, M. Shanty Town and City: The Case of Poona. Prog. Plan. 1981, 15, 151-269. [CrossRef]

24. PMC (Pune Municipal Corporation). Revising/Updating the City Development Plan (CPD) of Pune City-2041 under JNUURM. 2012. Available online: http://www.punecorporation.org/en/project-documents (accessed on 2 September 2017).

25. PMC (Pune Municipal Corporation). Draft Development Plan for old Pune City (2007-2027); PMC: Pune, India, 2013.

26. UNDESA (United Nations, Department of Economic and Social Affairs, Population Division World Urbanization Prospects. The 2014 Revision). 2014. Available online: http:/ / esa.un.org/unpd/wup/CD-ROM/WUP2014_XLS_ CD_FILES/WUP2014-F19-Urban_Population_Annual.xls (accessed on 2 September 2017).

27. Gadgil, A. Rainfall characteristics of Maharashtra. In Geography of Maharashtra; Diddee, J., Jog, S.R., Kale, V.S., Datye, V.S., Eds.; Rawat Publications: Jaipur, India, 2002; pp. 89-102.

28. Gunnell, Y. Relief and climate in South Asia: The influence of the Western Ghats on the current climate pattern of peninsular India. Int. J. Climatol. 1997, 17, 1169-1182. [CrossRef]

29. Wagner, P.D.; Waske, B. Importance of spatially distributed hydrologic variables for land use change modelling. Environ. Model. Softw. 2016, 83, 245-254. [CrossRef]

30. Padhye, A.D.; Mahabaleshwarkar, M.; Ghate, H.V. An overview of amphibian fauna of Pune District with special reference to their status in and around Pune City. Zoos Print J. 2002, 17, 757-763. [CrossRef]

31. Dahanukar, N.; Paingankar, M.; Raut, R.N.; Kharat, S.S. Fish fauna of Indrayani River, northern Western Ghats, India. J. Threat. Taxa 2012, 4, 2310-2317. [CrossRef]

32. Kharat, S.; Dahanukar, N.; Raut, R.; Mahabaleshwarkar, M. Long-term changes in freshwater fish species composition in North Western Ghats, Pune District. Curr. Sci. 2003, 84, 816-820.

33. Nalawade, S.; Padhye, A.; Utkarsh, G. Pune City Wilderness: A case for urban biodiversity assessment. J. Ecol. Soc. 2000, 13, 3-7.

34. GoM (Government of Maharashtra). Economic Survey of Maharashtra 2014-15; GoM: Mumbai, India, 2015.

35. Deshpande, R.; Palshikar, S. Occupational mobility: How much does caste matter? Econ. Political Wkly. 2008, $43,61-70$.

36. Sidhwani, P. Spatial inequalities in big Indian Cities. Econ. Political Wkly. 2015, 50, 55-62.

37. PMC (Pune Municipal Corporation). Pune Smart City_Vision Document (Version 1.0) Volume II. 2015. Available online: http:/ / www.punecorporation.org/en/project-documents (accessed on 2 September 2017).

38. Magarpatta City. 2014. Available online: http://magarpattacity.com/magarpattacity/farmer-story/walk-tomodel/ (accessed on 2 September 2017).

39. Butsch, C. Zugang zu Gesundheitsdienstleistungen. Barrieren und Anreize in Pune, Indien; Steiner Verlag: Stuttgart, Germany, 2011.

40. IIPS (International Institute for Population Sciences) and OCR Macro. National Family Health Survey (NFHS-2), 1998-99; IIPS: Mumbai, India, 2000. 
41. Benninger, C.C. Poona the Emergence of a Metropolis. In Million Cities of India Growth Dynamics, Internal Structure, Quality of Life and Planning Perspective; Vol, I., Misra, R.P., Misra, K., Eds.; Sustainable Development Foundation: New Delhi, India, 1998; pp. 384-417.

42. Sinha, B.N. Industrial Geography of India; The World Press: Calcutta, India, 1972.

43. Athreye, S.S. The Indian software industry and its evolving service capability. Ind. Corp. Chang. 2005, 14, 393-418. [CrossRef]

44. Kumar, K. Workforce Structure in Indian Metropolises. Geo Anal. 2014, 4, 43-51.

45. Kraas, F. Megacities and global change in East, Southeast and South Asia. Asien 2007, 103, 9-22.

46. Roy, A. Why India cannot plan its cities: Informality, insurgence and the idiom of urbanization. Plan. Theory 2009, 8, 76-87. [CrossRef]

47. Kulabkar, P. The politics of implementing urban plans in India: The case of Pune's development plan. Int. Dev. Plan. Rev. 2002, 24, 77-103. [CrossRef]

48. Victory for Punekars, No Construction on Bio Diversity Park Lands I Latest News \& Updates at Daily News \& Analysis. 2015. Available online: http://www.dnaindia.com/india/report-victory-for-punekars-noconstruction-on-bio-diversity-park-lands-2111799 (accessed on 22 November 2017).

49. Bio Diversity Park Reservation on Pune City's Hills to Stay / The Indian Express. Available online: http: / /indianexpress.com/article/cities/pune/bio-diversity-park-reservation-on-pune-citys-hills-to-stay / (accessed on 22 November 2017).

50. Nallathiga, R.; Tewari, K.; Saboo, A.; Varghese, S. Evolution of Satellite township development in Pune: A Case Study. Conference Paper. Available online: https:/ / www.researchgate.net/publication/270894930_ Evolution_of_Satellite_township_development_in_Pune_A_Case_Study (accessed on 22 November 2017).

51. Comptroller \& Auditor General. Performance Audit on Jawaharlal Nehru National Urban Renewal Mission; Report No.15; Comptroller \& Auditor General: New Delhi, India, 2012.

52. Vanolo, A. Smartmentality: The smart city as disciplinary strategy. Urban Stud. 2014, 51, 883-898. [CrossRef]

53. Butsch, C.; Kroll, M.; Kraas, F.; Bharucha, E. How is Rapid Urbanization in India Affecting Human Health? Findings from a Case Study in Pune. Asien 2015, 134, 73-93.

54. Kroll, M.; Bharucha, E.; Kraas, F. Does rapid urbanization aggravate health disparities? Reflections on the epidemiological transition in Pune, India. Glob. Health Action 2014, 7, 23447-23456. [CrossRef] [PubMed]

55. PMC (Pune Municipal Corporation). Pune Municipal Corporation Integrated Waste Management. Wealth from Waste. 2016. Available online: http://www.punesmartcity.in/wp-content/document/Smart_Project/07. \%2012\%20Page\%20Brochure\%20SWM.pdf (accessed on 2 September 2017).

56. Chikarmane, P.; Narayan, L. Organizing the Unorganized: A Case Study of the Kagad Kach Patra Kashtakari. Panchayat (Trade Union of Waste-Pickers). 2005. Available online: http://www.wiego.org/resources/ organising-unorganised-case-study-kagad-kach-patra-kashtakari-panchayat-trade-union-waste(accessed on 6 December 2017).

57. Chikarmane, P. Integrating Waste Pickers into Municipal Solid Waste Management in Pune, India; WIEGO Policy Brief. 2012. Available online: http://www.wiego.org/sites/default/files/publications/files/ Chikarmane_WIEGO_PB8.pdf accessed on 6 December 2017).

58. Kraas, F.; Kroll, M. Steuerungsprobleme aufsteigender Megastädte-Zur Reorganisation der Abfallwirtschaft von Pune/Indien. Geogr. Rundsch. 2008, 60, 56-61.

59. PMC (Pune Municipal Corporation). Reimagining Pune-Mission Smart Pune. 2015. Available online: http:/ / www.punecorporation.org/en/project-documents (accessed on 2 September 2017).

60. Joshi, R.; Ahmed, S. Status and challenges of municipal solid waste management in India: A review. Cogent Environ. Sci. 2016, 2, 1139434-1139452. [CrossRef]

61. Harvey, D. Cities or urbanization? City 1996, 1, 38-61. [CrossRef]

62. Shaw, A. Emerging Patterns of Urban Growth in India. Econ. Political Wkly. 1999, 34, 969-978.

63. Baviskar, A. Between violence and desire: Space, power, and identity in the making of metropolitan Delhi. Int. Soc. Sci. J. 2003, 55, 89-98. [CrossRef]

64. Rakodi, C. Forget planning, put politics first? Priorities for urban management in developing countries. Int. J. Appl. Earth Obs. Geoinform. 2001, 3, 209-223. [CrossRef]

65. Bhan, G. Planned illegalities. Econ. Political Wkly. 2013, 48, 59-70. 
66. Kraas, F.; Butsch, C. Wo beginnt die Stadt? Transformation und urbane Pfadabhängigkeiten in Pune/Indien. In Stadt und Land. Zwischen Status Quo und Utopischem Ideal; Berr, K., Friesen, H., Eds.; Lit.-Verlag: Münster, Germany, 2016; pp. 155-179.

67. Molotch, H. The city as a growth machine: Toward a political economy of place. Am. J. Sociol. 1976, 82, 309-332. [CrossRef] 